\title{
The Structure of Emotional Intelligence, Spiritual Intelligence and Its Relationship with Work Enthusiasm and Auditor Performance
}

\author{
Rusdiah Hasanuddin \\ School of Economics STIE-YPUP Makassar \\ Indonesia \\ Herman Sjahruddin \\ School of Economics STIEM Bongaya Makassar \\ Indonesia
}

Received: May 11, 2017

Accepted: June 2, 2017

Published: June 10, 2017

doi:10.5296/wjbm.v3i1.11321

URL: http://dx.doi.org/10.5296/wjbm.v3i1.11321

\begin{abstract}
This study aimed to test empirically the effect of emotional and spiritual intelligence to the enthusiasm of the work and performance of auditors. The study population was auditor who works at Public Accountant Office and Ministry of Finance of Indonesia South Sulawesi region. Online distribution of questionnaires carried out and from the results of the questionnaire, obtained 91 questionnaires that can be analyzed. Instrument research measured using Likert Scale point 1 to point 5. Engineering variance-based SEM (SEMPLS) with WarpPLS 5.0 used in this study. The results of the study provide evidence that emotional intelligence positive and significant effect on work enthusiasm. High spiritual intelligence in the same direction but did not significantly affect the increase in the work enthusiasm. Emotional intelligence has an insignificant effect on auditor performance. Spiritual intelligence has a real effect to improve the auditors' performance. Work enthusiasm has a positive and significant effect on auditors' performance. Emotional intelligence through the work enthusiasm has a significant effect on auditors' performance. Spiritual intelligence through work enthusiasm has an insignificant effect on auditors' performance.
\end{abstract}

Keywords: Emotional intelligence, Spiritual, Work enthusiasm, Auditor performance 


\section{Introduction}

The success key in the organization can be seen from the performance achieved individual, therefore, organizations require individuals to show optimal performance for both the poor performance achieved individual will affect the performance and success of the organization as a whole (Yuniningsih, 2002, p. 18). An issue regarding performance is a problem that will always be faced by the management of the organization, because the management needs to determine the factors that affect the individuals' performance. Factors that may affect the individual's performance will make the management of the organization can take the necessary policies, so as to improve individual performance to match the e organizational expectations (Habibah, 2001, p. 28). Factors that affect the performance of individuals among them are education and training, discipline, attitude and work activities, motivation, employment, health, income, social security, work environment, technology and production facilities, employment opportunities, as well as the need for achievement. These factors affect the individual in carrying out the tasks given to the individual (Ravianto, 1988, p. 20).

Individual performance is not only seen perfect working ability, but also the ability to control and manage themselves as well as the ability to build relationships with others (Martin, 2000, p. 22). Appropriate individuals in the organization is not easy, because it takes the organization not only individuals who are better educated or talented individuals alone, there are psychological factors that underlie the relationship between the individual and the organization. Psychological factors that affect the ability of individuals in the organization which is the ability to manage yourself, initiative, optimism, ability to control emotions, as well as the ability to think calmly without emotion (Boyatzis \& Ron, 2001, p. 2).

Emotional intelligence, including empathy, express, understand the feelings, anger control, self-reliance, adaptability, preferably, interpersonal problem-solving skills, perseverance, loyalty, friendliness, and respect. This shows that not only the intellectual superiority (IQ) is needed to achieve the kind of success but other skills needed to be a leader (Paige et al., 2001). In general, people believe that the intelligence in particular his intellectual ability is a form of mental abilities that are important in carrying out the task or job. This is understandable because the work is not only the actions to carry out the work but also intelligence to solve problems (Izard, 2001, p. 19). Intellectual intelligence alone is not grossly inadequate, because the intellect is only a tool (Riggio, 2000, p. 43).

The findings were obtained rebuttal, that the intelligence influential in shaping an efficient productivity in a person (Suhariadi, 2002, p. 348). One other form of intelligence that is currently popular is spiritual intelligence. Spiritual intelligence allows one to think of creative, resourceful away, making or even change the rules, which make the individual, can work better. Briefly spiritual intelligence is able to integrate two other capabilities that previously have mentioned that IQ and EQ (Choiriah, 2013). Spiritual intelligence is able to make a complete individual as being intellectually, emotionally and spiritually (Zohar \& Marshall, 2000). Being a smart individual who is not only expressed by having a high IQ, but to be truly intelligent, the individual is required to have a spiritual intelligence (SQ) (Ghozali, 2002). 


\section{$\triangle$ Macrothink}

The observations were made on auditors working in the Office of Public Accountants and Auditors at the Ministry of Finance of the Republic of Indonesia South Sulawesi Area was found to be the auditor who complained from the leadership, enthusiasm low work and the level of compliance of individual low due to the quality of relationships and communication Low, Problems enthusiasm to work and the performance of the auditor is a problem often faced by auditors, for that, the management needs to determine the factors that affect the performance of the auditor, because by understanding the factors that affect the performance of the management to take the necessary policy, so as to improve the performance of auditors in accordance with the expectations of the organization. Urge or force a soul and body movement to do, so that the motif as a stimulant of desire and power to move someone because each motif has a desire to achieve a goal (Hasibuan, 1999, p. 67).

Work enthusiasm is how to encourage morale, to work hard to take advantage of all the capabilities and all its potential to achieve organizational goals. Work enthusiasm is expected to provide an optimal contribution to the growth and development of the individual so that the vision, mission and goals of the organization can be realized. Problems can be identified and facts found in encouraging enthusiasm the work of auditors, that the auditor's behavior during this time based on the quantity and quality of work and timeliness used in the auditor's work tends to be low, so the impact on the performance of auditors. This is because the developments of a very high work while on the other hand tend to be low quality development auditor. Then the workload and quality of work are likely to be disproportionately, as well as awards to the auditor tends to be low. Initiatives in the works that have not been good due to the communication between the auditor is not running as it should, there is an overlap between the work of the other occupations, so the impact on the low enthusiasm to work and the auditors performance.

\section{Literature review}

\subsection{Emotional Intelligence}

Emotional intelligence is the ability to use emotions effectively manages them and affects relationships with others in a positive (Goleman, 2000, p. 51). Emotional intelligence is the ability to feel emotions, accept and build emotions well, understand emotions and emotional knowledge that can improve the emotional and intellectual development (Salovey et al., 1999). There a five concepts of emotional intelligence, namely, the ability to recognize emotions, managing emotions, motivating oneself, recognizing emotions fabric, and the ability to build relationships with others (Mayer et al., 1999). Emotional intelligence in it including the ability to control themselves, spur, persevere, and be able to motivate yourself. The skills include the management of emotions both positive and negative (Goleman, 2000).

Using of emotion that will effectively reach the goal in building productive relationships and achieve job success (Patton, 1998). Past studies show that emotional intelligence has a positive influence on a person's work and performance. Emotional intelligence is associated with human resource management systems, for example for training, in this case emotional intelligence can be used as a basis to provide training in particular. The training provides results that increase individual performance (Boyatzis, 1999). 
Some previous researchers proved that emotional intelligence is a significant and positive effect on the individual's involvement in the organization (Devi, 2016). Emotional intelligence has a direct impact on job involvement (Karimi \& Karimi, 2016). Emotional intelligence significantly effect on job satisfaction (Supriyanto \& Troena, 2012). Improved performance can be achieved through control of high emotion; empirical evidence indicates that emotional intelligence is a significant effect on the performance of auditors (Puspita Dewi \& Tenaya, 2017; Prasetya \& Kuswati, 2017; Lassk \& Shepherd, 2017; Wibowo, 2017; Trihandini, 2005; Supriyanto \& Troena, 2012).

Measurements of emotional intelligence in this study (Goleman, 2001), including (1) Self awareness is the ability of the auditor to determine their inner feelings and effect and use it to make decisions for yourself, have a benchmark that is realistic, or abilities and have confidence strong then associate it with the source of the cause, (2) Self-management is the auditor's ability to handle their own emotions, express and control emotions, a sense of the heart, to be used in relationships and everyday actions, (3) desire an auditor's ability to using a desire for any time stimulating and effort to achieve a better state and able to take initiative and act effectively, able to survive the failure and frustration, (4) Empathy (social awareness) the auditor's ability to sense what is perceived by others, ability to understand others' perspective, and give rise to a relationship of trust and be able to align themselves with the type of individual, and (5) Relationship management, the auditor's ability to handle emotions well when dealing with others and to create and maintain relationships with others, could affect, lead, deliberation, resolve disputes and work together in teams.

\subsection{Spiritual Intelligence}

Spiritual intelligence is defined as moral sense, the ability to adjust the rigid rules coupled with understanding and love and equal ability to see when the love and understanding to the limit, it also allows us to grapple with the matter of good and evil, imagine that has not happened, and lift us out of humility (Zohar \& Marshall, 2001, p. 37). Another view explaining that spiritual intelligence is a feeling of deep intuition toward connectedness with the wider world in our lives (Eckersley, 2000, p. 5).

The concept of spiritual intelligence in relation to the world of work consists of spiritual intelligence as the value of life from the inside, as the work has meaning and community (Ashmos \& Duchon, 2000, p. 6). Past studies with the spiritual intelligence distinguish religious attitudes in the workplace. Religious attitude is more aimed at the relationship with God while spiritual intelligence is more focused on a deep and bonded relationship between men and if it were widely (Mccormick 1994; Mitroff \& Denton, 1999). Spiritual intelligence (SQ) to facilitate dialogue between thought and emotion, between soul and body, spiritual intelligence can also help individuals to be able to perform self-transcendence (Berman, 2001).

Spiritual intelligence arise because of the debate about intellectual intelligence (IQ) and emotional intelligence (EQ), IQ and EQ seen only donating a portion of the determinants of individual success in life. There are other factors that come into play that spiritual intelligence (SQ) more emphasis on the meaning of life and not just limited to the suppression of religion 
(Hoffmann, 2002, p. 131). Individuals who have a high SQ are a person who has strong principles and vision, able to interpret every side of life and be able to manage and survive the hardship and pain (Nggermanto, 2002; Supriyanto \& Troena, 2012). Empirical evidence shows that the Spiritual quotient is a necessary means to identify and utilize limited resources to advance the work of the organization through the enthusiasm he displays (Akhtar et al., 2017). Five dimensions of spirituality have a significant impact on the ability of members of the organization to perform its obligations (Rego \& Cunha, 2008). Spiritual intelligence affects the individual performance (Wibowo, 2017; Anasrulloh, 2017; Supriyanto \& Troena, 2012; Trihandini, 2005). Measurement of spiritual intelligence includes; (1) must be honest, as a determinant of success in life in the world except to say correctly and consistently the truth is absolute honesty, (2) the auditor has the ability to be open to do the job, (3) the auditor has self-knowledge is good, (4) focus on the contribution that the issuance of the work, and (5) non-dogmatic spiritual, this component represents the value of spiritual intelligence, the ability to be flexible and have a high level of awareness (Zohar \& Marshall, 2000; Sukidi, 2002).

\subsection{Work Enthusiasm}

The enthusiasm of the work is an attempt to do the work vigorously so that jobs can be completed faster and better (Nitisemito, 1988). Enthusiasm to work is attitudes in work are typically characterized by their confidence, strong self-motivation to continue the work, joy, and good organization (Wilson, 1993). Enthusiasm to work is the inner atmosphere of influential individuals in the effort to achieve a goal through the implementation of work under his responsibility (Nawawi, 1990). High working enthusiasm can be attributed to the motive and the result of good work. While the low employment enthusiasm usually associated with frustration, aversion, lack of encouragement and the work will be unfavorable. Because the decline in enthusiasm to work a lot of them could be because the wages are too low, incentives are less effective, as well as poor working environment.

The fall enthusiasm of one's own work will have an impact on the involvement of the job and the organization. Enthusiasm assumed low employment can lower the individual loyalty towards the organization which then lowers performance (Moekijat, 1989). There are four aspects, namely the working enthusiasm excitement or enthusiasm, the quality to survive, the strength to fight frustration and spirit groups (Maier, 1995). Empirical evidence suggests that high working enthusiasm shown to improve the performance of auditors (Sangki et al., 2014). Enthusiasm to work used to describe atmosphere the overall felt by people in work, enthusiasm to work a significant effect on performance (Handayani, 2016).

Measurement of work enthusiasm (Nitisemito, 1992), includes: (1) the attitude of pro-active, that is its pro active auditor to be involved in training and education programs, whether internally or externally, (2) the compensation they get used as stimuli to work better, (3) placement in accordance competencies are respondents to the placement of the auditor in the work in accordance with the competence, work experience and educational background you have, (4) the working environment conducive to the respondents to the efforts of auditors who strives to create and maintain an atmosphere and work environment that is very 
conducive, (5) meet the needs of non-material auditors are respondents to the attitude of the leadership which always take the policy benefit, so that the auditor can meet the needs of non-material, such as health and appreciation for the work accomplished.

\subsection{Auditor Performance}

Etymologically, the performance comes from the work performance (performance). The term is derived from the performance of job performance or the actual performance (performance or achievements actually reached someone) that results in quality and quantity of work accomplished by individuals in carrying out their duties in accordance with the responsibilities given to him (Mangkunagara, 2005, p. 67). Performance can be divided into two, namely the performance of individual and organizational performance. Individual performance is the result of individual work in terms of both quality and quantity based on the standard of work that has been determined, while the performance of the organization is a combination of individual performance with the performance of the group (Mangkunagara, 2005, p. 15).

Individual performance is a measure that can be used to set the comparison results of the implementation of tasks, responsibilities given by the organization at a certain period and the relative can be used to measure job performance or the performance of the organization (Gibson et al., 1996, p. 95). Performance of auditors is an action or implementation of inspection tasks that have been completed by the auditor within a certain time. Auditor performance by are accountants who carry out the assignment of the examination (examination) objectively on the financial statements of some other organizations with the aim to determine whether the financial statements are presented fairly in accordance with generally accepted accounting principles, in all material respects, the financial position and results of operations auditor (Mulyadi, 1998, p. 11).

Auditor performance as an evaluation of the work carried out by superiors, peers, self, and direct reports (Kalbers \& Forgarty, 1995) There are four dimensions of personality in measuring the performance of auditors, among others: (1) the ability(ability), professional commitment, motivation and job satisfaction. An auditor who has the ability in terms of auditing it will be proficient in completing the work. Auditors are committed to the profession it will be loyal to his profession as perceived by the auditor. The motivation of an individual auditor will encourage the desire to perform certain activities for (Abel \& Larkin, 1990). This study elicits the measurement of the performance of auditors (Trisnaningsih, 2004), namely (1) the ability, (2) commitment to the profession, (3) motivation, and (4) of job satisfaction, by adding (5) fraud as additional indicators in analyzing the performance of auditors.

\section{Method}

The study population was auditor who works at Public Accountant Office and Ministry of Finance of Indonesia South Sulawesi region. Online distribution of questionnaires carried out and from the results of the questionnaire, obtained 91 questionnaires that can be analyzed. Instruments measured using Likert Scale point 1 to point 5. Engineering variance-based SEM 
(SEMPLS) with a WarpPLS 5.0 developed by Kock (2010) used in this study.

\section{Results}

\subsection{Description of Respondents}

The identity of respondents such as gender, age, level of education and working life, served to determine the number of frequencies and percentages of respondents' representative presence in response. Shown as follows:

Table 1. Characteristics of respondents

\begin{tabular}{|c|l|c|c|}
\hline \multicolumn{2}{|c|}{ characteristics of respondents } & Frequency $(n=91)$ & Percent $(\%)$ \\
\hline \multirow{3}{*}{ Gender } & Male & 69 & 75,82 \\
\cline { 2 - 4 } & Female & 22 & 24,18 \\
\hline \multirow{3}{*}{ Age (years) } & $31-40$ & 21 & 23,08 \\
\cline { 2 - 4 } & $41-50$ & 47 & 51,65 \\
\cline { 2 - 4 } & $\geq 51$ & 23 & 25,27 \\
\hline \multirow{3}{*}{$\begin{array}{c}\text { Level of education } \\
\text { Years of work } \\
\text { experience }\end{array}$} & Graduate degree program & 56 & 61,54 \\
\cline { 2 - 4 } & Masters program & 31 & 34,07 \\
\cline { 2 - 4 } & Doctoral program & 4 & 4,40 \\
\cline { 2 - 4 } & $\leq 10$ & 14 & 15,38 \\
\cline { 2 - 4 } & $11-20$ & 51 & 56,04 \\
\hline
\end{tabular}

The table shows that the frequency of respondents by sex with men is characterized by 69 $(75.82 \%)$ while the rest of the women indicated by $22(24.18 \%)$. Most of the respondents had ages between $41-50$ years (51.65\%); with the majority of the Graduate Degree level education program $56(61.54 \%)$, as well as working life $11-20$ years were $51(56.04 \%)$.

\subsection{Goodness of Fit Model}

P-value for the average path coefficient (APC) and the ARS and the R-squared value Average (ARS) must be $<0.05$ or significant meaning. Additionally Average full collinearity VIF (AFVIF) as an indicator of multicollinearity should $<5$. The results showed that the results of the model fit tests (goodness of fit model) have been fulfilled (Kock, 2011).

Table 2. Test the conformity of the model

\begin{tabular}{|l|l|l|}
\hline \multicolumn{1}{|c|}{ Measurement } & \multicolumn{1}{c|}{ Model 1 } & \multicolumn{1}{c|}{ Model 2 } \\
\hline Average path coefficient (APC) & $0.208, \mathrm{P}=0.010$ & $0.193, \mathrm{P}=0.014$ \\
\hline Average R-squared (ARS) & $0.140, \mathrm{P}=0.042$ & $0.156, \mathrm{P}=0.031$ \\
\hline Average adjusted R-squared (AARS) & $0.116, \mathrm{P}=0.064$ & $0.132, \mathrm{P}=0.049$ \\
\hline Average block VIF (AFVIF) & 1.021, acceptable if $<=$ & $\begin{array}{l}1.128, \text { acceptable if }<= \\
5, \text { ideally }<=3.3\end{array}$ \\
\hline
\end{tabular}

Source: Data processed (SEMPLS, 2017). 


\subsection{Result of Validity Test and Construct Reliability}

Table 3a. Combined loading and cross-loadings (Model 1)

\begin{tabular}{|c|c|c|c|c|c|c|c|}
\hline Indicators & Emotio & Spiritu & Enthusi & Auditor & Type (a & SE & P value \\
\hline $\mathrm{X}_{11}$ & $(0.689)$ & 0.113 & -0.194 & -0.032 & Reflect & 0.086 & $<0.001$ \\
\hline $\mathrm{X}_{12}$ & $(0.787)$ & 0.179 & 0.212 & -0.066 & Reflect & 0.084 & $<0.001$ \\
\hline $\mathrm{X}_{13}$ & $(0.601)$ & -0.189 & -0.274 & 0.435 & Reflect & 0.088 & $<0.001$ \\
\hline $\mathrm{X}_{14}$ & $(0.556)$ & -0.100 & 0.071 & -0.105 & Reflect & 0.089 & $<0.001$ \\
\hline $\mathrm{X}_{15}$ & $(0.570)$ & -0.087 & 0.162 & -0.226 & Reflect & 0.089 & $<0.001$ \\
\hline $\mathrm{X}_{21}$ & -0.026 & $(0.606)$ & -0.281 & 0.233 & Reflect & 0.088 & $<0.001$ \\
\hline $\mathrm{X}_{22}$ & -0.031 & $(0.873)$ & -0.103 & 0.018 & Reflect & 0.082 & $<0.001$ \\
\hline $\mathrm{X}_{23}$ & 0.022 & $(0.792)$ & -0.090 & 0.019 & Reflect & 0.084 & $<0.001$ \\
\hline $\mathrm{X}_{24}$ & 0.045 & $(0.807)$ & 0.187 & -0.023 & Reflect & 0.083 & $<0.001$ \\
\hline $\mathrm{X}_{25}$ & -0.015 & $(0.689)$ & 0.263 & -0.224 & Reflect & 0.086 & $<0.001$ \\
\hline $\mathrm{Y}_{11}$ & -0.040 & 0.092 & $(0.850)$ & 0.094 & Reflect & 0.082 & $<0.001$ \\
\hline $\mathrm{Y}_{12}$ & 0.106 & -0.083 & $(0.709)$ & 0.010 & Reflect & 0.086 & $<0.001$ \\
\hline $\mathrm{Y}_{13}$ & 0.164 & 0.122 & $(0.054)$ & -0.336 & Reflect & 0.103 & 0.301 \\
\hline $\mathrm{Y}_{14}$ & 0.220 & 0.096 & $(-0.306)$ & -0.192 & Reflect & 0.096 & 0.001 \\
\hline $\mathrm{Y}_{15}$ & 0.031 & 0.007 & $(0.553)$ & -0.228 & Reflect & 0.090 & $<0.001$ \\
\hline $\mathrm{Z}_{11}$ & -0.119 & 0.019 & 0.148 & $(0.632)$ & Reflect & 0.088 & $<0.001$ \\
\hline $\mathrm{Z}_{12}$ & 0.109 & 0.107 & -0.179 & $(0.640)$ & Reflect & 0.087 & $<0.001$ \\
\hline $\mathrm{Z}_{13}$ & 0.035 & 0.055 & -0.109 & $(0.762)$ & Reflect & 0.084 & $<0.001$ \\
\hline $\mathrm{Z}_{14}$ & 0.013 & -0.150 & -0.027 & $(0.776)$ & Reflect & 0.084 & $<0.001$ \\
\hline $\mathrm{Z}_{15}$ & -0.044 & -0.007 & 0.176 & $(0.713)$ & Reflect & 0.086 & $<0.001$ \\
\hline
\end{tabular}

Source: Data processed (SEMPLS, 2017).

Measurement model or models of the outer construct validity and reliability. This output is used investigators to report the test results of the convergent validity of the measurement instrument (questionnaire). In the table $3 \mathrm{a}$ combined loading and cross-loadings still a construct validity konvergennya $<0,70$ (although $\mathrm{p}$-value $<0.05$ ) and should be removed from the model, as shown in the following table: 


\section{Macrothink}

World Journal of Business and Management

ISSN 2377-4622

2017, Vol. 3, No. 1

Table 3b. Combined loading and cross-loadings (Model 2)

\begin{tabular}{|c|c|c|c|c|c|c|c|}
\hline Indicators & Emotio & Spiritu & Enthusi & Auditor & Type (a & SE & P value \\
\hline $\mathrm{X}_{12}$ & $(1.000)$ & 0.000 & -0.000 & 0.000 & Reflect & 0.079 & $<0.001$ \\
\hline $\mathrm{X}_{22}$ & 0.065 & $(0.917)$ & -0.105 & -0.016 & Reflect & 0.081 & $<0.001$ \\
\hline $\mathrm{X}_{23}$ & -0.134 & $(0.847)$ & -0.060 & 0.038 & Reflect & 0.082 & $<0.001$ \\
\hline $\mathrm{X}_{24}$ & 0.067 & $(0.807)$ & 0.182 & -0.022 & Reflect & 0.083 & $<0.001$ \\
\hline $\mathrm{Y}_{11}$ & -0.079 & 0.095 & $(0.846)$ & 0.065 & Reflect & 0.082 & $<0.001$ \\
\hline $\mathrm{Y}_{12}$ & 0.079 & -0.095 & $(0.846)$ & -0.065 & Reflect & 0.082 & $<0.001$ \\
\hline $\mathrm{Z}_{13}$ & 0.054 & 0.109 & -0.116 & $(0.738)$ & Reflect & 0.085 & $<0.001$ \\
\hline $\mathrm{Z}_{14}$ & -0.066 & -0.083 & 0.003 & $(0.842)$ & Reflect & 0.082 & $<0.001$ \\
\hline $\mathrm{Z}_{15}$ & 0.020 & -0.014 & 0.105 & $(0.788)$ & Reflect & 0.084 & $<0.001$ \\
\hline
\end{tabular}

Source: Data processed (SEMPLS, 2017).

Assay results in Table $3 \mathrm{~b}$ indicate that the convergent validity criteria unmet model 1 and model 2 is fulfilled having already qualified, convergent validity of $>0.70$ and significant (p-value < 0.05) so that model 2 used for the analysis. (Hair et al., 2013).

\subsection{Discriminant Validity Test}

Discriminant validity test proved me pass the output latent variable correlations. This output reports the correlation coefficient between the latent variables. The criteria used are the square roots (square roots) average variance extracted (AVE) is a column diagonal bracketed must be higher than the correlation between latent variables in the same column (above or below) (Sholihin \& Dwi, 2013).

Table 4. Correlations among l.vs. with sq. rts. of AVEs (Model 2)

\begin{tabular}{|c|c|c|c|c|}
\hline Variables & Emotio & Spiritu & Enthusi & Auditor \\
\hline Emotio & 1.000 & 0.264 & 0.189 & 0.192 \\
\hline Spiritu & 0.264 & 0.858 & 0.126 & 0.245 \\
\hline Enthusi & 0.189 & 0.126 & 0.846 & 0.337 \\
\hline Auditor & 0.192 & 0.245 & 0.337 & 0.791 \\
\hline
\end{tabular}

Source: Data processed (SEMPLS, 2017).

The table shows that the discriminant validity has been met, which can be seen from the root of AVE on the diagonal column is greater than the correlation between constructs in the same column. The results of this cross-loading has an indication of fulfillment the validity diskriminant criteria.

\subsection{Reliability Test Construct}

Construct reliability test results can be shown by the output coefficient latent variable, as in the following table: 
Table 5. Output latent variable coefficient (Model 2)

\begin{tabular}{|l|c|c|c|c|}
\hline \multicolumn{1}{|c|}{ Measurement } & Emotio & Spiritu & Enthusi & Auditor \\
\hline R-squared coefficients & & & 0.139 & 0.172 \\
\hline Adjusted R-squared coefficients & & & 0.119 & 0.144 \\
\hline Composite reliability coefficients & 1.000 & 0.893 & 0.835 & 0.833 \\
\hline Cronbach's alpha coefficients & 1.000 & 0.819 & 0.604 & 0.699 \\
\hline Average variances extracted & 1.000 & 0.736 & 0.716 & 0.625 \\
\hline Full collinearity VIFs & 1.113 & 1.122 & 1.149 & 1.193 \\
\hline Q-squared coefficients & & & 0.153 & 0.184 \\
\hline \multirow{2}{*}{ Minimum and maximum values } & -3.151 & -2.459 & -2.393 & -2.880 \\
\cline { 2 - 5 } & 2.000 & 1.397 & 2.669 & 2.012 \\
\hline \multirow{2}{*}{ Medians (top) and modes (bottom) } & 0.283 & 0.450 & 0.081 & -0.083 \\
\cline { 2 - 5 } & 0.283 & 0.450 & 0.982 & 0.381 \\
\hline \multirow{2}{*}{$\begin{array}{l}\text { Skewness (top) and exc. kurtosis (bottom) } \\
\text { coefficients }\end{array}$} & -1.329 & -0.864 & -0.157 & -0.214 \\
\cline { 2 - 5 } & 2.904 & 0.037 & -0.342 & 0.611 \\
\hline
\end{tabular}

Source: Data processed (SEMPLS, 2017).

The coefficient of determination (R-squared) that shows what percentage of the variance of the construct of an endogenous / criterion can be explained by the construct hypothesized effect. The higher the R-squared shows a good model. From the results of the latent variable output coefficient R-squared shows the enthusiasm of 0139 work means work enthusiasm can be explained variance of $13.90 \%$ by the variance of emotional intelligence and spiritual intelligence, while the R-squared to construct the performance of auditors for 0172 shows that the variance can be explained by the performance of auditors $17.20 \%$ by the variance of work enthusiasm.

Reliability composite value and have qualified cronbach alpha reliability that is $>0.70$. The output also shows that the average variance extracted (AVE) $>0.50$, which means meets the requirements of convergent validity (Sholihin, A \& Dwi R, 2013). Full collinearity (VIF) is a full colinearity test results which include vertical and lateral multicollinearity. Lateral collinearity is collinearity between the latent variables predictor with the criterion. lateral collinearity often overlooked when can cause the results to be biased.

Full collinearity (VIF) in this research value is lower than 3.3 it indicates that the model is free from the problem of vertical or lateral colinearity, and common methods bias (Kock, 2013). Q-squared is a measure of non-parametric obtained through the algorithm blindfolding and used to study the predictive validity or relevance of a set of latent predictor variables on criterion variables. The output shows Q-squared is greater than zero, namely 0153 and 0184 means that the estimated model shows a good predictive validity. Overall, the result of measurement models (outer model) reflective construct has been qualified.

\subsection{Model and Hypothesis Testing}

The models and hypothesis testing results showed that, among the five causality between 
variables (direct effect) are built in this model, there is a causality between the two variables reject the hypothesis that the influence of emotional intelligence on the auditors performance $\mathrm{p}$-value $=0.197>0.05$ and influence of spiritual intelligence on work enthusiasm p-value $=$ $0.276>0.05$

$\mathrm{H}_{1}$ : Effect of emotional intelligence on work enthusiasm.

Emotional intelligence influence on the enthusiasm of the work can be evidenced by standardized path coefficients (beta) of 0,352 with a positive direction. Standardized path coefficient is positive, explaining that emotional intelligence high proven to increase the enthusiasm of the work of auditors. Then it can be proven with $\mathrm{p}$-value $=0,001<0.05$. The test results prove the hypothesis that emotional intelligence positive and significant effect on the enthusiasm to work, it can be concluded that emotional intelligence unidirectional and real high to increase the working enthusiasm of Auditors, so that the hypothesis $\left(\mathrm{H}_{1}\right)$ emotional intelligence positive and significant effect on work enthusiasm can be accepted or supported by empirical facts.

Emotional intelligence high direct current and real to increased enthusiasm to work Auditors due to the high ability of the auditor to handle their own emotions, express and control emotions, a sense of the heart, to be used in relationships and everyday actions that have an impact on the attitudes of pro-active auditors to engage on training and education programs, whether internally or externally and the high compensation that they get used as stimuli to work better.

High emotional intelligence has an impact on an individual's ability to face the challenges and make it as individuals responsible, productive, and optimistic in the face and solve problems, where these things are needed in the work environment. The use of emotion that will effectively goal in building productive relationships and achieve job success (Patton, 1998). These results support the findings of previous researchers that emotional intelligence and significant positive effect on the individual's involvement in the organization (Devi, 2016). Emotional intelligence has a direct impact on job involvement (Karimi \& Karimi, 2016). Emotional intelligence significantly effect on job satisfaction (Supriyanto \& Troena, 2012).

$\mathrm{H}_{2}$ : Effect of Spiritual Intelligence on work enthusiasm.

Effect of spiritual intelligence on work enthusiasm can be evidenced by standardized path coefficients (beta) of 0,061 with a positive direction. Standardized path coefficient is positive, explaining that the high spiritual intelligence owned auditors tend to increase the enthusiasm of the work of auditors. Then it can be proven with p-value $=0,276>0.05$. Hypothesis testing results prove that spiritual intelligence has a positive and insignificant effect on work enthusiasm, it can be concluded that the high spiritual intelligence in the same direction but did not significantly affect the increase in the enthusiasm of the work of auditors, so the hypothesis $\left(\mathrm{H}_{2}\right)$ spiritual intelligence positive and significant effect on the work enthusiasm cannot be accepted or not supported by empirical facts.

The effect is positive but not significant due to the auditor have the ability to be open to do 
the job, the auditor has the self-knowledge that good and focus on the contribution that the issuance of the work, but intelligence does not provide any real effect on the attitude of pro-active auditor to be involved in the program education and training and the compensation they receive to be used as stimuli in the work. This study supports the findings of previous investigators partially, that Spiritual quotient is a necessary means to identify and utilize limited resources to advance the work of the organization through the enthusiasm he displays (Akhtar et al., 2017).

$\mathrm{H}_{3}$ : Effect of emotional intelligence on auditors' performance.

Effect of emotional intelligence on auditor performance can be demonstrated by standardized path coefficients (beta) of 0,088 with a positive direction. Standardized path coefficient is positive, explaining that the high emotional intelligence tend to improve the auditor performance. Then it can be proven with $\mathrm{p}$-value $=0,197>0.05$. The test results prove the hypothesis that the emotional intelligence is positive but insignificant effect on auditor performance, it can be concluded that the high emotional intelligence in the same direction but not significant increase in auditor performance, so the hypothesis $\left(\mathrm{H}_{3}\right)$ emotional intelligence positive and significant effect on auditors performance no acceptable or not supported by empirical facts.

The cause of the positive and significant effect of emotional intelligence on auditor performance, caused because the auditor's ability high to deal with his own emotions, express and control emotions, a sense of the heart used in relationships and everyday actions cannot increase the ability of auditors to further to work better and improve the auditor's ability to prevent fraud as well as the feeling of satisfaction is very high in the auditor's work.

The results support the partially findings of previous research, that the performance improvement can be achieved through control of high emotion, that emotional intelligence is a significant effect on auditor performance (Puspita Dewi \& Tenaya, 2017; Prasetya \& Kuswati, 2017; Lassk \& Shepherd, 2017: Wibowo, 2017; Trihandini 2005: Supriyanto \& Troena, 2012).

$\mathrm{H}_{4}$ : Effect of spiritual intelligence on auditors' performance.

Effect of spiritual intelligence on auditor performance can be evidenced by standardized path coefficients (beta) of 0,169 with a positive direction. Standardized path coefficient is positive, explaining that the high spiritual intelligence tends to improve the auditor performance. Then it can be proven with $\mathrm{p}$-value $=0,047<0.05$. Hypothesis testing results prove that spiritual intelligence positive and significant effect on auditor performance, it can be concluded that the high spiritual intelligence in the same direction and real improvement on auditor performance, so the hypothesis $\left(\mathrm{H}_{4}\right)$ spiritual intelligence positive and significant effect on auditors performance can be accepted or supported by empirical facts.

Causality unidirectional and meaningful, due to auditor has the ability to be open to do the job, the auditor has the self-knowledge that good and focus on the contribution that the issuance of the work so that with these efforts, the more increases the ability of the auditor to perform better and prevent fraud as well as a sense of satisfaction within the auditor's very 


\section{$\triangle$ Macrothink}

high in the works. This study is relevant to the findings of previous investigators, that the five dimensions of spirituality have a significant impact on the ability of members of the organization to perform its necessity (Rego \& Cunha, 2008). Spiritual intelligence affects on the individual performance (Wibowo, 2017; Anasrulloh, 2017; Supriyanto \& Troena, 2012; Trihandini, 2005).

$\mathrm{H}_{5}$ : Effect of work enthusiasm on auditors' performance.

Work enthusiasm effect on auditor performance can be demonstrated by standardized path coefficients (beta) of 0.295 with a positive direction. Standardized path coefficient is positive, explaining that the auditor high enthusiasm in the work tends to improve the auditor performance. Then it can be proven with $p$-value $=0.001<0.05$. Hypothesis testing results prove that the work enthusiasm positive and significant effect on auditor performance, concluded that the high level work enthusiasm in the same direction and significantly to the improvement on auditor performance, so the hypothesis $\left(\mathrm{H}_{5}\right)$ work enthusiasm positive and significant effect on auditors performance can be accepted or supported by empirical facts.

Significant influence due to the high desire auditor to air its pro active, involved in training and education programs as well as the compensation they receive to be used as stimuli in the work thus providing a significant effect on the auditor's ability to work better and prevent fraud and complacency within the auditor's very high in the works. The findings of this study support the findings of previous researchers, that a high work enthusiasm shown to improve the performance of auditor (Sangki et al., 2014). Enthusiasm to work used to describe atmosphere the overall felt by people in work, work enthusiasm has significant effect on individual performance (Handayani, 2016).

$\mathrm{H}_{6}$ : The mediating role of work enthusiasm in explaining the effect of emotional intelligence on auditors' performance.

Effect of mediation work enthusiasm in analyzing the effect of emotional intelligence on the performance of auditors can be verified by calculation using the sobel test tool preacher X1 $==>Y==\mathbf{Z}$

\begin{tabular}{|c|c|c|c|c|}
\hline Input: & & Test statistic: & Std. Error: & $p$-value: \\
\hline a 0.352 & Sobel test: & 2.36532069 & 0.04390102 & 0.01801446 \\
\hline$b \longdiv { 0 . 2 9 5 }$ & Aroian test: & 2.31587662 & 0.04483831 & 0.02056501 \\
\hline$s_{a} 0.095$ & Goodman test: & 2.4180732 & 0.04294328 & 0.01560294 \\
\hline$s_{\mathrm{b}} 0.096$ & Reset all & & Calculate & \\
\hline
\end{tabular}

Figure 1. The Sobel mediation test (First)

Based on sobel calculations using the preacher tool on the figure 2 for mediation work enthusiasm in explaining the effect of emotional intelligence on auditors performance obtained $\mathrm{t}_{\text {-statistic }}(2,36532)>\mathrm{t}$-table $(1,96)$ and $\mathrm{p}$-value $0,018<0.05$, which means significant. 
Referring to the results, it can be concluded that there are significant results the mediating role of work enthusiasm in explaining the effect of emotional intelligence on auditors' performance.

$\mathrm{H}_{7}$ : The mediating role of work enthusiasm in explaining the effect of spiritual intelligence on auditors' performance.

Effect of mediation work enthusiasm in analyzing the effect of spiritual intelligence on auditor performance can be verified by calculation using sobel test preacher tool $X_{2}==Y$ $==>\mathrm{Z}$

\begin{tabular}{|c|c|c|c|c|}
\hline Input: & & Test statistic: & Std. Error: & $p$-value: \\
\hline a 0.061 & Sobel test: & 0.5815314 & 0.03094416 & 0.56088236 \\
\hline b 0.295 & Aroian test: & 0.55393793 & 0.03248559 & 0.57962133 \\
\hline$s_{a} 0.103$ & Goodman test: & 0.61370704 & 0.02932181 & 0.53940894 \\
\hline$s_{\mathrm{b}} 0.096$ & Reset all & & Calculate & \\
\hline
\end{tabular}

Figure 2. The Sobel mediation test (second)

Based on sobel calculations using the preacher tool on the Figure 3 for mediation work enthusiasm in explaining the effect of spiritual intelligence on auditors performance obtained $\mathrm{t}_{\text {-statistic }}(0,58153)<\mathrm{t}$-table $(1,96)$ and $\mathrm{p}$-value $0,560>0.05$, which means insignificant. These results prove that there was not significant, the role of work enthusiasm in explaining the effect of spiritual intelligence on the performance of auditors.

\section{Conclusions and Discussion}

Emotional intelligence high unidirectional and meaningful to increased work enthusiasm due to the high ability of the auditor to deal with his own emotions, the auditor has a sensitivity to conscience, to be used in relationships and everyday actions that have an impact on the attitudes of pro-actively involved in the training program and education, either internally or externally and the high compensation that they get used as stimuli to work better. Auditors have the ability to be open to do the job, the auditor has the self-knowledge that good and focus on the contribution that the issuance of the work, but intelligence does not provide any real effect on the attitude of pro-active auditor to be involved in training and education programs and compensation they earn to serve as stimuli in the work.

The high ability of auditors to handle their own emotions, express and control emotions, a sense of the heart cannot increase the ability of auditors to further work better and improve the auditor's ability to prevent fraud as well as the feeling of satisfaction is very high in the auditor's work. Auditors have the ability to be open to do the job, the auditor has the self-knowledge that good and focus on the contribution that the issuance of the work so that with these efforts, the more increases the ability of the auditor to perform better and prevent fraud and complacency within the auditor's very high in the works. 


\section{Mll Macrothink}

World Journal of Business and Management

ISSN 2377-4622

2017, Vol. 3, No. 1

The high ability of auditors to atmosphere its proactive, involved in training and education programs as well as the compensation they receive to be used as stimuli in the work thus providing a significant effect on the auditor's ability to work better and prevent fraud and complacency within the auditor very high in the works. Emotional intelligence significant effect on the performance of auditors through work enthusiasm, this fact is inversely proportional to spiritual intelligence no significant effect on auditors performance through work enthusiasm needed seriousness to improve the intelligence of emotional auditor through, the auditor's ability to know their inner feelings and have strong confidence.

Increase the desire to evoke the spirit and energy and was able to take the initiative and act effectively. The ability to sense what is perceived by others and the auditor's ability to handle emotions well when dealing with others and in consultation, resolve disputes and work together in teams. Auditors in the work required to be honest has the ability to be flexible and as well as a high level of self-awareness in working as an effort to increase the spiritual intelligence. Increased enthusiasm auditor's work may be done by placing the auditors in accordance with the job competence, work experience and educational background they have.

\section{References}

Abel, J. L., \& Larkin, K. T. (1990). Anticipation of performance among musicians: Physiological arousal, confidence, and state-anxiety. Psychology of Music, 18(2), 171-182. https://doi.org/10.1177/0305735690182006

Akhtar, S., Akhtar, S., Arshad, M. A., Mahmood, A., \& Ahmed, A. (2017). Spiritual quotient towards organizational sustainability: the Islamic perspective. World Journal of Entrepreneurship, Management and Sustainable Development, 13(2), 163-170. https://doi.org/10.1108/WJEMSD-01-2017-0002

Anasrulloh, M. (2017). Contribution Spiritual Intelligence on Employee Performance at Bank Muamalat Tulungagung. Journal of Economic Education, 1(2).

Ashmos, D. P., \& Duchon, D. (2000). Spirituality at work: A conceptualization and measure. Journal of Management Inquiry, 9(2), 134-145. https://doi.org/10.1177/105649260092008

Berman, M. (2001). Developing SQ (Spiritual Intelligence) Through ELT. Retrieved from http://www.spiritualintelligence.com

Boyatzis, R. E. (1999). Self-directed change and learning as a Necessary meta-competency for success and effectiveness in the twenty-first century. Keys to Employee Success in Coming Decades, 15-32.

Boyatzis, R. E., \& Ron, S. (2001). Unleashing the Power of Self Directed Learning, Case Western Reserve University. USA: Cleveland, Ohio.

Choiriah, A. (2013). Effect of Emotional Intelligence, Intellectual Intelligence, Spiritual Intelligence and Performance against Auditor Professional Ethics in Public Accounting Firm. Journal of Accounting, 1(1). 


\section{I Macrothink}

World Journal of Business and Management

ISSN 2377-4622

2017, Vol. 3, No. 1

Devi, S. (2016). Impact of spirituality and emotional intelligence on employee engagement. International Journal of Applied Research, 2(4), 321-325.

Eckersley, R. (2000). Spirituality, Progress, Meaning, and Values. Paper Presented 3rd Annual Conference on Spirituality, Leadership, and Management, Ballarat, 4 December.

Ghozali, I. (2002). Effect of Religiosity, Against Organizational Commitment, Job Involvement, Job Satisfaction and Productivity. Journal of Business and Strategy, 9, 1-13.

Gibson, I., \& Donnelly. (1996). Organizations: Behavior, Structure, Processes. Translated by Ninuk Adriani. Jakarta: Script Binarupa

Goleman, D. (2000). Emotional Intelligence: Why Emotional Intelligence Higher Than IQ. Gramedia Pustaka Utama, Jakarta.

Goleman, D. (2001). Emotional intelligence: Issues in building paradigm. The Emotionally Intelligent Workplace, 13, 26.

Habibah, S. (2001). Improving Performance Through Mechanism 360 Degrees. Assessing Business, 2(1), 27-37.

Hair, J. F., Hult, G. T. M., Ringle, C. M., \& Sarstedt, M. (2013). A Primer on Partial Least Squares Structural Equation Modeling (PLS-SEM). Thousand Oaks: Sage.

Handayani, R. D. (2016). Environmental Influence on Performance and Morale Pns Balitsa Lembang. Tourism Journal, 2(1), 40-50.

Hasibuan, M. S. P. (1999). Organization and Motivation. DasarPeningkatan. Productivity. Jakarta: BumiAksara.

Hoffman, E. (2002). Psychological Testing at Work. The McGraw-Hill Companies. New York.

Izard, C., Fine, S., Schultz, D., Mostow, A., Ackerman, B., \& Youngstrom, E. (2001). Emotion knowledge as a predictor of social behavior and academic competence in children at risk. Psychological science, 12(1), 18-23. https://doi.org/10.1111/1467-9280.00304

Kalbers, L. P., \& Fogarty, T. J. (1995). Professionalism and its Consequences: A study of internal auditors. Auditing, 14(1), 64.

Karimi, Z., \& Karimi, F. (2016). The structural models of relationship between spiritual intelligence and emotional intelligence with quality of work life and work engagement of employees. International Journal of Management in Education, 10(3), 278-292. https://doi.org/10.1504/IJMIE.2016.077508

Kock, N. (2010). Using e-collaboration WarpPLS in studies: An overview of the main five analysis steps. International Journal of e-Collaboration (IJEC), 6(4), 1-11. https://doi.org/10.4018/jec.2010100101

Kock, N. (2011). Using e-collaboration WarpPLS in studies: Descriptive statistics, settings, and key analysis results. International Journal of e-Collaboration, 7(2), 1-17. https://doi.org/10.4018/jec.2011040101 


\section{Macrothink}

World Journal of Business and Management

ISSN 2377-4622

2017, Vol. 3, No. 1

Kock, N. (2013). Using WarpPLS in E-Collaboration Studies: Descriptive Statistics, Settings. Interdisciplinary Applications of Electronic Collaboration Approaches and Technologies, 62. https://doi.org/10.4018/978-1-4666-2020-9.ch005

Lassk, F. G., \& Shepherd, C. D. (2017). Self-Efficacy and Salesperson Job Involvement as mediators of the Emotional Intelligence Creativity Relationship. In The Customer is NOT Always Right? Marketing Orientationsin a Dynamic Business World (pp. 716-716). Springer, Cham. https://doi.org/10.1007/978-3-319-50008-9_192

Maier, N. R. F. (1995). Psychology in industry. Houghton Mifflin Company, Boston.

Mangkunagara, A. P. (2005). Human Resources company. Juveniles. Rosdakarya: Bandung.

Martin, A. D. (2000). Competence Model, New Trends Revitalization HR. Jakarta: PT Refika Aditama.

Mayer, J. D., Caruso, D. R., \& Salovey, P. (1999). Emotional intelligence meets traditional standards for an intelligence. Intelligence, 27(4), 267-298. https://doi.org/10.1016/S0160-2896(99)00016-1

McCormick, D. W. (1994). Spirituality and management. Journal of Managerial Psychology, 9(6), 5-8. https://doi.org/10.1108/02683949410070142

Mitroff, II, \& Denton, E. A. (1999). A study of spirituality in the workplace. MIT Sloan Management Review, 40(4), 83-92.

Moekijat. (1989). Personnel management. PT. Mandar Maju. Bandung.

Mulyadi. (1998). Accounting System. Yogyakarta: BPFE

Nawawi, H. (1990). Personnel Administration: For Improved Productivity. Jakarta.

Nggermanto, A. (2002). Quantum Quotient (Intelligence Quantum): How to jump-start the IQ, $E Q$ and $S Q$ In Harmony. Nuance: Bandung.

Nitisemito, A. S. (1992). Human Resources Management. UGM BPFE.

Paige, N. M., Hays, R. D., Litwin, M. S., Rajfer, J., \& Shapiro, M. F. (2001). Improvement in emotional well-being and relationships of users of sildenafil. The Journal of Urology, 166(5), 1774-1778. https://doi.org/10.1016/S0022-5347(05)65673-X

Patton, P. (1998). EQ Platform for Achieving Personal Success and Career. Jakarta: PT Mitra Media.

Prasetya, A. D., \& Rini, K. S. E. (2017). Analysis of Effect of Emotional Intelligence and Spiritual Intelligence on Employee Performance at PDAM Sragen (Doctoral dissertation, University of Muhammadiyah Surakarta).

Puspita Dewi, I., \& Tenaya, A. I. (2017). Effect of Professional Ethics, Self Efficacy, Spiritual Intelligence, Intellectual Intelligence, and Emotional Intelligence on Auditor performance. E-Journal of Accounting, 19(1), 654-682. 
Ravianto. (1988). Production of Management. Jakarta: LSIUP

Rego, A., \& Pina e Cunha, M. (2008). Workplace spirituality and organizational commitment: an empirical study. Journal of Organizational Change Management, 21(1), 53-75. https://doi.org/10.1108/09534810810847039

Riggio, H. R. (2000). Measuring attitudes toward adult sibling relationships: The lifespan of sibling relationship scale. Journal of Social and Personal Relationships, 17(6), 707-728. https://doi.org/10.1177/0265407500176001

Salovey, P., Bedell, B. T., Detweiler, J. B., \& Mayer, J. D. (1999). Coping intelligently. Coping, 141-164.

Sangki, R. Y., Kojo, C., \& Sendow, G. M. (2014). Work Environment, Work Culture and Morale on Employee Performance Outsourcing at Telkomsel Grapari Manado. Journal of Economic Research, Management, Business and Accounting, 2(3).

Sholihin, M., \& Dwi, R. (2013). SEM-PLS with WarpPLS 3.0. Andi. Yogyakarta.

Suhariadi, F. (2002). Effect of Intelligence and Spirit Motivation on Completion in Shaping Behavior Efficient Productive. Anima: Indonesian Journal of Psychology, 17(4), 346.

Sukidi. (2002). Spiritualized Education, Major Budi Character Education. Compass.

Supriyanto, A. S., \& Troena, E. A. (2012). Effect of Emotional Intelligence and Spiritual Intelligence on Transformational Leadership, Job Satisfaction and Performance Manager (Studies in Shariah Banking Malang). Application Management Journal, 10(4), 693-17.

Trihandini, R. F. M. (2005). Analysis of Effect of Intellectual Intelligence, Emotional Intelligence and Spiritual Intelligence on Employee Performance (Case Study at Hotel Horison Semarang) (Doctoral dissertation, Diponegoro University Graduate Program).

Wibowo, C. T. (2017). Analysis of the influence of emotional intelligence (EQ) and spiritual intelligence (SQ) on employee performance. Journal of Business and Management, 15(1), $1-16$.

Wilson, C. (1993). Enthusiasm and its critics: Historical and modern perspectives. History Of European Ideas, 17(4), 461-478. https://doi.org/10.1016/0191-6599(93)90135-D

Yuninigsih. (2002). Building Commitment, performance and Creating Human Resources For Success Company. Economic Focus, 1(1)

Zohar, D., \& Marshall, I. (2001). SQ: Take advantage of spiritual intelligence in thinking | integrative and holistic as the meaning of life. Mizan.

Zohar, D., \& Marshall. (2000). I. SQ: Connecting with Our Spiritual Intelligence. New York: Bloomsbury. 


\section{Macrothink}

\section{Appendix}

Appendix 1. The path coefficients and p-value (Model 2)

\begin{tabular}{|c|l|l|l|l|l|l|l|l|}
\hline \multicolumn{5}{|c|}{ Path coefficients } & \multicolumn{5}{c|}{ P-values } \\
\hline Variables & Emotio & Spiritu & Enthusi & Auditor & Emotio & Spiritu & Enthusi & Auditor \\
\hline Emotio & & & & & & & & \\
\hline Spiritu & & & & & & & & \\
\hline Enthusi & 0.352 & 0.061 & & & $<0.001$ & 0.276 & & \\
\hline Auditor & 0.088 & 0.169 & 0.295 & & 0.197 & 0.047 & 0.001 & \\
\hline
\end{tabular}

Source: Data processed (SEMPLS, 2017).

Appendix 2. Figure of Hypothesis testing

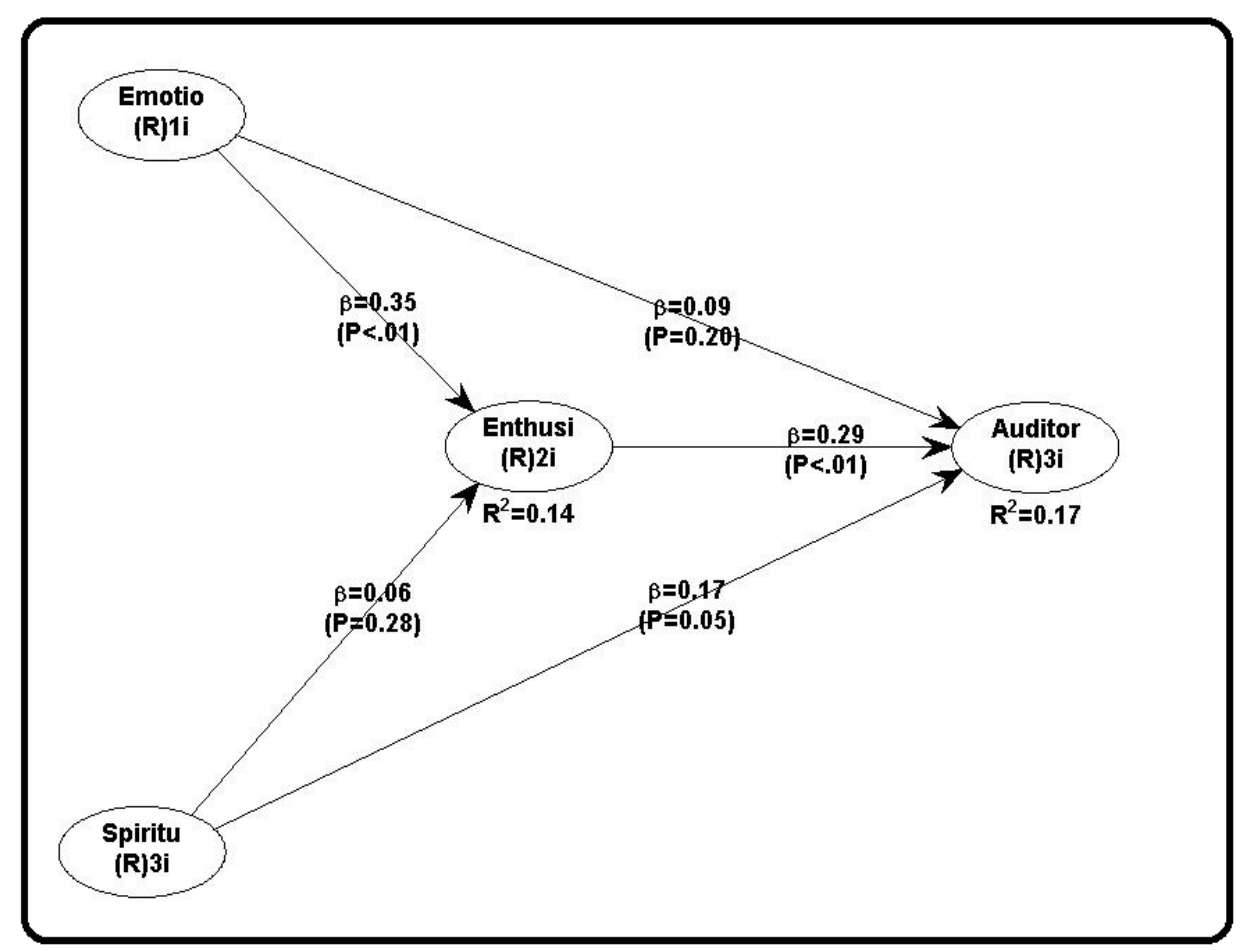

Source: Data processed (SEMPLS, 2017).

\section{Copyright Disclaimer}

Copyright for this article is retained by the author(s), with first publication rights granted to the journal.

This is an open-access article distributed under the terms and conditions of the Creative Commons Attribution license (http://creativecommons.org/licenses/by/3.0/). 